\title{
First Crack and Yield Load of Fanpalm Reinforced Concrete Slabs
}

\author{
Audu M. T. ${ }^{1}$, Oseni O.W ${ }^{2}$ \\ ${ }^{1,2}$ Department of Civil Engineering, University of Abuja, FCT, Abuja, Nigeria
}

\begin{abstract}
The importance of cracks and crack width in reinforced concrete member is so vital and is considered as a very important parameter under serviceabity limit state design of concrete elements. Fanpalm is one of the locally available and has been studied as a suitable alternative to steel reinforcements. The need to study the cracks and cracks' patterns for concrete slabs reinforced with fanpalm is the concern of this study. Fanpalm specimens were cut, shaped to desired flexural reinforcements sizes. Then used as reinforcements for concrete slabs of 1:2:4 mix and cured in water for 28 days. Flexural strength tests were carried out to evaluate the load causing the first visible crack and the load causing full development of yield lines of fanpalm reinforcement concrete slabs were observed. The theoretical yield load is lower compared with the observed experimental yielding loads. The results reveal that the cracks increases with increased in load. As the load systematically increases there is another sudden changes in deflection at yield points. The highest percentage reinforcement $72 \%$ and $65 \%$ on $y$ and $x$ plane respectively occurred on slab SL2 with corresponding value of $15.4 \mathrm{kN}$ and $29.48 \mathrm{kN}$ of yield load and First crack load respectively.
\end{abstract}

Keywords: First crack, yield load, fanpalm, reinforced concrete, slab

\section{Introduction}

Cracks and yield lines play important role in structural failure of reinforced concrete members. The failure of well designed reinforced concrete members are often preceded by formation of cracks. These cracks increased in numbers and widths as the structures tend to yield point. In reinforced concrete elements, there is an acceptable limit to the width of crack after which the structure is assumed to have failed. Hence, the need to examine the cracks behaviors and yield line formation in natural fibre, reinforced concrete members becomes inevitable. Concrete is a composite inert material comprising of a binder course (e.g cement), mineral filler (aggregates) and water, Neville, 1989. Aggregates are of two types, fine and coarse. They are usually graded from sand to stone. There are two types of concrete; light weight concrete and dense concrete. The light weight concrete weighed between 1600 to $2000 \mathrm{~kg} / \mathrm{m}^{3}$, while the dense concrete has an average density of $2400 \mathrm{~kg} / \mathrm{m}^{3}$ (Orchard, 1976). Dense concrete is often used for reinforced concrete works.

The batching of concrete can either be by weight or by volume. The batching of design mix for high quality jobs is usually by weight. The amount of water to be added to a batch of concrete mix is governed by the workability, strength and the exposure condition. If too much of water is added there is tendency for aggregate segregation during placing and concrete not meeting the target strength after hardened. While, too little of water in a mix, will not make the chemical action of setting of cement to be incomplete. The amount of water to be added to a given batch of concrete mix is guided by specified water cement ratio.

For structural concrete members that are subjected to compressive and tensile stress, it is often required that reinforcement introduced at the tensile zone of the member because concrete is very good in compression but weak in tension. Such reinforcements should be of material that has high tensile stress, good bonding with concrete and durable in alkaline media. Section 7 of BS 8110, 1987, specified that concrete reinforcements should comply with BS4499 and BS 4461 and that different reinforcement may be used in the same structural member. In any case, the reinforcement used in concrete must be durable. Steel reinforcement was found suitable and have long been used as reinforcements in concrete members. But attention is now focusing on natural fibre as a possible reinforcing material in concrete to reduce cost. This paper examines the use of fan palm as a reinforcing material in concrete slabs.

The possibilities of using fanpalm as reinforcement in structural members have developed a grown interest in recent years. The fanpalm is local wood belonging to the family of palmacea commonly found in the tropical countries and widely spread in the middle belt of Nigeria. Their physical and mechanical property as well as its durability condition makes it a possible substitute to steel reinforcements. Investigation is therefore necessary to establish its suitability as a substitute to steel reinforcements.

\section{Review of Literature}

The use of Bamboo, farm palm and some selected woods to replace conventional steel reinforcement in reinforced concrete members. (Slabs, beams, columns) have received attention over the past fifteen years. Mechanical properties of these materials such a the yield stress the load-defection characteristics and absorption characteristics of these local fibers as well as the composite behavior have been investigated by Fache (1986), Ibi (1988), Modola (1976), Audu (2000) are few examples.

Fache (1983) reported that fanpalm air-dried specimen has the tensile strength within the range $80-120 \mathrm{~N} / \mathrm{mm}^{2}$ while the compressive strength within $40-90 \mathrm{~N} / \mathrm{mm}^{2}$. Ibi (1988) recorded that air-dried specimen to have average moisture content of $11.66 \%$ and the ultimate tensile strength to be $131.18 \mathrm{~N} / \mathrm{mm}_{2}$ while the average ultimate compressive strength were fund to be $71.6 \mathrm{~N} / \mathrm{mm}^{2}$. Ibi (1998) also investigate the variation of ultimate strengths (tensile and 


\section{International Journal of Science and Research (IJSR) \\ ISSN (Online): 2319-7064 \\ Index Copernicus Value (2013): 6.14 | Impact Factor (2014): 5.611}

compressive) when soaked in water. It was observed that the ultimate strength decrease with increase in moisture content up to $28-32 \%$ after which there is increase in ultimate strength again up to $40 \%$ moisture content. Thereafter, there is decrease in ultimate strength as moisture content increases.

Audu (2015) immerse uncoated fanpalm reinforced beams, beans reinforced with fanpalm coated with, blocking agents and water repellant agents in $0.1 \mathrm{NaOH}$ solution over a period of 365 days. The uncoated (untreated) fanpalm beams has sharp decrease in strength with time.

Kankan (1986) investigated the flexible strength and crack behavior or bamboo reinforced composite. He found out that the experimental failure load is about $67 \%$ of the designed load based on concrete section alone.

Concrete in aggressive environment suffers four major types of deterioration: corrosion of the reinforcement, alkaliaggregate reactivity, freeze - thaw deterioration and attack by sulphates (Ozyildirim, 1993). Most structures may be exposed to sulphate and chloride salts and various acids because of environmental pollution; the type of action of these salts on the concrete varies. An investigation of $\mathrm{Na}+$, $\mathrm{Cu} 2+, \mathrm{Mg} 2+, \mathrm{Ca} 2+, \mathrm{NH} 4+$ sulphate solutions on truss cements, showed that the most aggressive solution is NH4+ sulphates (Kilinckale, 1974). It has been noted that, concrete exposed to sulphates attack loses compressive strength and this loss increases as a function of sulphate concentration and age of exposure [Kilinckale and Uyan (1996)]. The effect of different sulphates solutions on compressive strength of concrete is not equally severe, the effect of magnesium sulphate is found to be one of the most severe [Kumar and Kameswa, (1994), Collepardi, Marciatis and Turiziani (1982),] in Afolayan and Alhassan (2010). It is also a known fact that the construction industry relies heavily on cement for its operations on the development of shelter and other infrastructural facilities. The provisions of low cost but durable materials are almost universally recognized as one of the major obstacles to improve housing conditions in developing countries. Among the building materials in use today, the ordinary Portland cement (OPC) is a vital element in all types of construction. OPC is expensive and has limited the construction of housing. It then becomes extremely difficult for majority of the people to own houses and many collapsed structure have been reported in an attempt to reduce cost ( Afolayan and Alhassan 2010)

\section{Materials and Method}

In carrying out the test, three sets of slab were casted using the same materials and subjected to the same curing and testing conditions.

Set I - Fanpalm reinforced concrete slabs (SL)

Set II - Unreinforced concrete slabs (SLU)

Set III - Steel reinforced concrete slab SLC $\left(\mathrm{Fy}=250 \mathrm{~N} / \mathrm{mm}^{2}\right)$.

Tap water, portland cement, washed erosion sand, granite of $20 \mathrm{~mm}$ max size and sliced fanpalm were used. Concrete mix of $0.82: 1: 3.5: 5.5$ that is the ratio of water, cement, fine aggregate, coarse aggregate to give average compressive strength $12.65 \mathrm{~N} / \mathrm{mm}^{2}$ was used for the production of three sets and then cured for 28 days under laboratory conditions. Nine numbers wooden molds of $880 \times 880 \times 70 \mathrm{~mm}$ were made. Fanpalm logs were sliced trimmed and smoothened to $10 \times 10 \mathrm{~mm}$ and $12 \times 12 \mathrm{~mm}$ reinforcements' sections using hack saw and smoothening machine. These reinforcements were placed in concrete molds. Concrete of mix ratio of 1 : $3.5: 5.5$ to meet the designed target strength of 12.65 $\mathrm{N} / \mathrm{mm}^{2}$ was made. The batching was by weight, while the mixings were done using concrete mixer. The concrete was poured to fill the molds containing the reinforcements. The fresh concrete then compacted gently with vibrating poker for 5 minutes. The molds were removed after 24 hours and the concrete slabs then soaked in water for 28 days. The slabs were removed and air dried for 2 hours before subjected to flexural strength test. The flexural strength tests were carried out on the fanpalm reinforced slab specimens thus; the specimens were placed on the steel knife edge supports of the Automatic Universal Testing Machine (AUTM). A fabricated steel plate $4 \mathrm{~mm}$ thick that covered the entire surface of the slabs was placed on slabs and the two under the universal testing machine. The load was applied uniformly at the rate of $1 \mathrm{kN} / \mathrm{mins}$ through the loading rate knob and the load/release knob of the AUTM. The loads at first cracks and loads at failure and the corresponding cracks were read and recorded.

\section{Result and Discussion}

\subsection{Result}

The results of the experimental investigation are presented in Tables 1, 2 and 3 below:

Table 1: Concrete properties of the slabs

\begin{tabular}{|c|c|c|c|}
\hline $\begin{array}{c}\text { Slab } \\
\text { No }\end{array}$ & $\begin{array}{c}\text { Dimension } \\
(\mathrm{mm}) \text { of Slabs }\end{array}$ & $\begin{array}{c}\text { Age at test } \\
(\text { days })\end{array}$ & $\begin{array}{c}\text { Average 28 days } \\
\text { cube strength } \\
(\mathrm{N} / \mathrm{mm} 2)\end{array}$ \\
\hline SL1 & $880 \times 880 \times 70$ & 82 & 16.50 \\
\hline SL2 & $880 \times 880 \times 70$ & 82 & 18.00 \\
\hline SL3 & $880 \times 880 \times 70$ & 82 & 16.70 \\
\hline SLU & $880 \times 880 \times 70$ & 82 & 17.60 \\
\hline SLC & $880 \times 880 \times 70$ & 82 & 17.80 \\
\hline
\end{tabular}

SL1- Fanpalm reinforced concrete slabs Type 1, SL2Fanpalm reinforced concrete slabs Type 2, SL3- Fanpalm reinforced concrete slabs Type 3, SLU - Unreinforced concrete

Slabs, SLC- Steel reinforced concrete slab SLC

Table 2: Percentage of reinforcement of the slabs

\begin{tabular}{|c|c|c|c|c|c|c|c|}
\hline \multirow{2}{*}{$\begin{array}{c}\text { Slab } \\
\text { No. }\end{array}$} & \multicolumn{2}{|c|}{ spacing } & \multicolumn{2}{c|}{ Area } & \multicolumn{2}{c|}{$\begin{array}{c}\text { Percentage of } \\
\text { reinforcement }\end{array}$} \\
\cline { 2 - 8 } & $\begin{array}{c}\text { Size } \\
(\mathrm{mm})\end{array}$ & $\begin{array}{c}\text { Sx } \\
(\mathrm{mm})\end{array}$ & $\begin{array}{c}\text { Sy } \\
(\mathrm{mm})\end{array}$ & $\begin{array}{c}\text { AFx } \\
\left(\mathrm{mm}^{2}\right)\end{array}$ & $\begin{array}{c}\text { AFy } \\
\left(\mathrm{mm}^{2}\right)\end{array}$ & $\begin{array}{c}100 \\
(\mathrm{AFx} / \mathrm{bh})\end{array}$ & $\begin{array}{c}100 \\
(\mathrm{AFy} / \mathrm{bh})\end{array}$ \\
\hline SL1 & $10 \times 10$ & 410 & 410 & 300 & 300 & 0.43 & 0.43 \\
\hline SL2 & $12 \times 12$ & 405 & 405 & 432 & 504 & 0.65 & 0.72 \\
\hline SL3 & $12 \times 11$ & 405 & 405 & 396 & 396 & 0.57 & 0.57 \\
\hline SLU & - & - & - & - & - & - & - \\
\hline SLC & $\Phi 12 \mathrm{~mm}$ & 410 & 410 & 339.3 & 226.7 & 0.59 & 0.52 \\
\hline
\end{tabular}




\section{International Journal of Science and Research (IJSR) \\ ISSN (Online): 2319-7064}

Index Copernicus Value (2013): 6.14 | Impact Factor (2014): 5.611

Table 3: First cracks and yield loads of the slabs

\begin{tabular}{|l|c|c|c|c|c|c|c|}
\hline & \multicolumn{2}{|c|}{ Experimental } & \multicolumn{2}{c|}{ Theoretical } & & \\
\hline Slab No & $\begin{array}{l}\text { Yield Load } \\
\mathrm{P}^{*}{ }_{\mathrm{x}}(\mathrm{kN})\end{array}$ & $\begin{array}{l}\text { First Crack Load } \\
\mathrm{P}_{\mathrm{y}}^{*}(\mathrm{kN})\end{array}$ & $\begin{array}{l}\text { Yield Load } \\
\mathrm{P}_{\mathrm{x}}(\mathrm{kN})\end{array}$ & $\begin{array}{l}\text { First Crack } \\
\text { Load } \mathrm{P}_{\mathrm{y}}(\mathrm{kN})\end{array}$ & $\frac{p_{y}^{*}}{P_{y}}$ & $\frac{P_{x}^{*}}{P_{x}}$ & $\begin{array}{l}\text { Crack } \\
\text { Pattern }\end{array}$ \\
\hline SLI & 21.15 & 17.98 & 8.44 & 20.98 & 0.85 & 2.49 & $\mathrm{Y}$ \\
\hline SL2 & 29.24 & 15.50 & 15.04 & 29.48 & 0.53 & 1.95 & $\mathrm{Y}$ \\
\hline SL3 & 23.55 & 9.42 & 11.76 & 23.40 & 0.40 & 1.99 & $\mathrm{Y}$ \\
\hline SLU & 0.28 & 12.27 & 0.28 & 12.27 & - & - & $\mathrm{Y}$ \\
\hline SLC & 68.45 & 22.59 & 44.21 & 45.95 & 0.33 & 1.04 & $\mathrm{~L}$ \\
\hline
\end{tabular}

$Y=y$ shape crack on the slabs

$L=$ shape crack on the slabs

\subsection{Discussion}

The results reveal that the crack increases with increased in load. As the load systematically increases there is another sudden change in deflection at yield points. The highest percentage reinforcement $72 \%$ and $65 \%$ on $\mathrm{y}$ and $\mathrm{x}$ plane respectively occurred on slab SL2 with corresponding value of $15.4 \mathrm{kN}$ and $29.48 \mathrm{kN}$ of yield load and First crack load respectively.

There is crack formation then followed by multiplication and increases of cracks as load increases. The load causing full development of yield lines as given in Table 3, shows that the theoretical yield load is always lower than the experimental yield loads. This could be attributed to the factor of safety often adopted in the design.

\section{Conclusion}

Fanpalm reinforcement composite behaves in like manner as steel reinforcement composite. The experimental failure load is always higher than the theoretical failure load. In conclusion the slab of these properties is preferred in construction that is slab SL2 of $880 \times 880 \times 70$ and age at 82 days.

\section{References}

[1] Audu, M. T. (2015): Durability Study of Fan Palm (Borassus Aethiopum) As a Reinforcing Material in Concrete. ph.D. Thesis Submitted to the Department of Civil Engineering, Ladoke Akintola University of of Technology, Ogbomoso, Oyo state, Nigeria..

[2] Afolayan , J.O. and Alhassan, A. Y. (2010): Durability of concrete containing fly ash (fa) in aggressive Environment. Journal of Engineering and Applied Sciences Volume 2, September 2010

[3] Collepardi, M, Marciatis, A. and Turiziani, R. (1982), Penetration of Chloride Ions in Cement Paste and in Concrete. J. Am. Ceram . Soc, 55 (10) 534- 535.

[4] Fache, J. O. (1983): Mechanical Properties and Pysical Characteristic of Fanpalm B. Eng. Project Report submitted to Department of Civil Engineering, University of Ilorin.

[5] Ibi, T. M. (1988): The Behaviour of Fanpalm Reinforced Concrete Beams and Slabs Subjected to short term loading. B. Eng. Project Report submitted to Department of Civil Engineering, University of Ilorin.

[6] Kankan, T. A. (1986): Bamb00 Reinforced Concrete Slabs subjected to concentrated Loading. MPil. Thesis, University of Science and Technology, Kumasi, Ghana.
[7] Kilinckale, F. M (1997), "The Effect of MgSO4 and HCL Solution on the Strength and Durability of Pozzolana Cement Mortars." Cement and Concrete Research, Vol. 27, No. 12, pp. 1911-1918.

[8] Kilinckale, F. M and Uyan, M; (1996), Turkish Chamber of Civil Engineers Technical journal 7, 1231.

[9] Kumar, S. and Kameswa C.V.S, (1994), Effect of Sulfates on the Setting Time of Cement and Strength of Concrete", Cement and Concrete Research, Vol 24, No7, pp 1237-1244.

[10] Neville, A.M. (1989), Properties of Concrete, Fifth edition, Longman Scientific and Technology, London.

[11] Orchard, D. F. (1976), Properties of Materials. Concrete Technology Vol. 1, ThirdEdition, Published by Applied Science Publisher Ltd. London.

[12] Ozyildirim, C. (1993), Durability of Concrete Bridges in Virginia. ASCE Structures Congress XI Proceedings; Structural engineering in natural hazards mitigation. New York: American Society of Civil Engineers, pp.996-1001. 